BEATA SZUBTARSKA (Łódź)

\title{
PRACE ATASZATU PRASOWEGO AMBASADY RP W ZSRR W LATACH 1941-1943
}

Ważną jednostką organizacyjną każdej placówki dyplomatycznej jest wydział prasowy, którego podstawowym celem jest prowadzenie działalności informacyjnej i propagandowej. Ambasada RP w ZSRR, reaktywowana w sierpniu 1941 r. po zawarciu układu Sikorski-Majski, przywiązywała do tej aktywności dużą wagę. Za realizację tej części pracy odpowiadał referat prasowy ambasady.

W ramach swoich podstawowych czynności referat miał gromadzić i przekazywać informacje oraz upowszechniać przyjazne stanowisko polskiego rządu emigracyjnego i Polaków w stosunku do spraw polsko-radzieckich. Propaganda skierowana miała być do:

- Polaków w ZSRR;

- radzieckiego społeczeństwa, w szczególności do opiniotwórczych kół dziennikarskich, artystycznych, literackich, naukowych;

- obcokrajowców w ZSRR, głównie dyplomatów i dziennikarzy zagranicznych;

- Polaków w kraju ${ }^{1}$.

Funkcję attaché prasowego objął we wrześniu 1941 r. Ksawery Pruszyński, publicysta, autor wielu reportaży wojennych, znany z przychylnego stosunku do Rosji i Rosjan². Zastępcą Pruszyńskiego był Teodor Parnicki

1 Instytut Polski i Muzeum im. gen. Sikorskiego (dalej IPMS), Zespół akt Ambasada RP w Kujbyszewie (dalej AK), sygn. A.7.307/38/1.

2 Pruszyński po powrocie do Londynu w 1942 r. wydał artykuł Wobec Rosji, w którym życzliwie wypowiadał się o ówczesnym ZSRR. Tekst wywołał niemałą burzę w środowiskach emigracyjnych i ostrą polemikę na łamach „Wiadomości Polskich” ze strony m.in. Z. Nowakowskiego, W. Wielhorskiego. Oskarżano go o sprzyjanie państwu komunistycznemu i wyrzeczenie się polskich ziem wschodnich. Patrz: K. Pruszyński, Publicystyka, t. 2, 1940-1948. Powrót do Soplicowa, Warszawa 1990, s. 230-239. 
(znany powieściopisarz i publicysta), który formalnie od lipca 1942 r., a faktycznie - na skutek ciężkiej choroby K. Pruszyńskiego ${ }^{3}$ - od kwietnia tego roku pełnił funkcję attaché prasowego. Od stycznia 1943 r. do momentu zerwania stosunków polsko-radzieckich stanowisko to piastował Jan Erdman (znany przed wojną dziennikarz sportowy). Dodać należy również, iż w referacie tym zatrudnionych było (lub czasowo współpracowało $z$ nim) wiele znakomitości polskiej literatury i polskiego dziennikarstwa oraz artystów. Spośród nich wymienić należy Herminę Naglerową, Wiktora Weintrauba, Władysława Broniewskiego, Bernarda Singera, Feliksa Topolskiego, Józefa Czapskiego ${ }^{4}$.

$\mathrm{Na}$ najważniejszym odcinku zadań referatu prasowego, czyli w miarę wszechstronnego informowania ludności polskiej przebywającej na terytorium ZSRR, prace ambasady rozpoczęły się niemalże od chwili jej reaktywowania w 1941 r. Była to niezmiernie istotna część pracy ataszatu. Kilkaset tysięcy polskich obywateli, którzy w różny sposób znaleźli się w. Związku Radzieckim i od prawie dwóch lat byli odcięci od świata, należało w pierwszej kolejności powiadomić o utworzeniu placówki dyplomatycznej RP i o planowanej akcji pomocy ${ }^{5}$.

W założeniach referatu działalność informacyjno-propagandowa miała być prowadzona przede wszystkim za pomoca prasy oraz audycji radiowych. Problem ten, jako bardzo istotny dla strony polskiej, poruszony został już przez Józefa Retingera w sierpniu 1941 r. podczas jego pierwszych spotkań z przedstawicielami Kremla. Narkomindieł nie ustalił z nim, co prawda, konkretnych rozwiązań, ale charge d'affaires otrzymał przychylne odpowiedzi na propozycje wydawania polskiej gazety i nadawania audycji radiowych dla obywateli $\mathrm{RP}^{6}$.

Kluczowe rozmowy w tej sprawie odbyły się 17 września $1941 \mathrm{r.}{ }^{7}$, kiedy to ambasador Kot spotkał się z Solomonem Łozowskim - wicekomisarzem

3 Pruszyński zachorował na tyfus.

4 Lista akredytowanych polskich dziennikarzy, literatów i artystów, IPMS, Zespół akt Prezes Rady Ministrów (dalej PRM), sygn. PRM 41/2.

5 Szeroko na ten temat patrz: D. Boćkowski, Czas nadziei. Obywatele Rzeczypospolitej Polskiej w ZSRR i opieka nad nimi placówek polskich w latach 1940-1943, Warszawa 1999.

6 Archiv Wnieszniej Politiki Rossijskoj Federacji (dalej AWPRF), sygn. fond 122, opis 24, papka 186, dieło 1, s. 2-3. IPMS, PRM, sygn. PRM 41/4.

7 AWPRF, sygn. f. 122 , op. 24 , p. 186 , d. 1, s. $31-38$. 
LKSZ do spraw kultury i propagandy ${ }^{8}$. Zasygnalizował najważniejsze jego zdaniem kwestie $z$ wiązane $z$ propagandą, czyli, oprócz już wymienionych, prosił o możliwość wydawania broszur i książek oraz odpowiadania na listy obywateli polskich do ambasady poprzez radio. Wynikiem tego spotkania było opracowanie przez ambasadę szczegółowych propozycji w sprawie wydawania tygodnika polskiego oraz książek i broszur, które przesłano do LKSZ 19 sierpnia 1941 r. Tego samego dnia Jan Tabaczyński (z ramienia referatu prasowego) w towarzystwie Wiesława Arleta rozmawiali z Puszkinem, zastępcą kierownika wydziału polskiego w Narkomindiele, do którego należały sprawy propagandowe. W czasie tej rozmowy ustalono zasady działalności polskiego radia na terenie ZSRR ${ }^{10}$. Szczegóły techniczne, dotyczące zarówno gazety, jak i radia, postanowiono omówić w najbliższych dniach $\mathrm{w}$ porozumieniu $\mathrm{z}$ odpowiedzialnym za sprawy techniczne w wydziale prasowym Narkomindiełu - Poługanowem.

We wspomnianym piśmie $z 19$ sierpnia ambasa przedstawiła potrzeby związane $z$ zamierzonym wydawaniem polskiego tygodnika oraz uzasadniała konieczność prowadzenia akcji propagandowej skierowanej do obywateli polskich na terenie ZSRR. Z perspektywy ambasady najważniejsze było utrzymanie woli zdecydowanej walki z Niemcami, kształtowanie opinii na rzecz porozumienia polsko-radzieckiego, szeroko pojęta informacja oraz działalność oświatowo-kulturalna ${ }^{11}$. Wszystkie te cele miała spełniać m.in. „Polska", którą planowano wydawać w pięćdziesięciotysięcznym nakładzie ${ }^{12}$. $\mathrm{Na}$ realizację tego ambitnego projektu „zapotrzebowano" w Narkomindiele nie tylko odpowiednią ilość papieru, ale także drukarnię, lokal na redakcję oraz maszyny $z$ łacińską czcionką.

Akcja propagandowa obejmować miała, oprócz gazety, również publikację książek i broszur. W planach wydawniczych znalazły się m.in.:

- Czarna Ksiega, zbiór dokumentów obrazujących okupację hitlerowską na ziemiach polskich, w przekładzie rosyjskim;

8 Poza tym w sprawach propagandy przedstawiciele ambasady mogli kontaktować się z Pietrowem, zastępcą dyrektora Działu Prasowego LKSZ, Poługanowem, kierownikiem oddziału druku, i jego zastępcą Oriechowem.

9 IPMS, PRM, sygn. PRM 41/2.

10 IPMS, PRM, sygn. PRM 42/5.

11 Bbidem, sygn. PRM 41/2.

12 W planach umieszczono również wydawanie około 2 tysięcy egzemplarzy dla ośrodków polskich na Bliskim Wschodzie, Anglii i Ameryce oraz 500-1000 do rozrzucenia w kraju. Ibidem. 
- Szkic informacyjny Pruszyńskiego o dwóch latach walki Polski z Niemcami;

- Porozumienie polsko-radzieckie z 30 lipca 1941 r. Wybór dokumentów;

- Szkice o walkach polskich lotników i marynarzy na frontach II wojny światowej;

- Śpiewnik polski $z$ nutami ${ }^{13}$.

Kolejny raz kwestie związane $z$ pracą referatu prasowego omawiane były 22 listopada w czasie spotkania Kota i Pruszyńskiego z Łozowskim ${ }^{14}$. Ustalono wtedy, że audycje radiowe w języku polskim nadawane będą cztery razy w tygodniu (wtorek, środa, sobota, niedziela), dwa razy po 10 minut dla Polaków w ZSRR (proponowana godzina emisji 18.15) i dwa razy po 10 minut do Warszawy (19.15). W sprawie maszyn do pisania uzyskano zapewnienie Łozowskiego o kontynuowanych staraniach, aby je przywieźć z Moskwy i dostarczyć do redakcji. Pozytywnie rozpatrzono prośbę o przydzielenie oddzielnego lokalu dla potrzeb gazety w przybudówce ambasady. Umożliwiło to przyspieszenie prac związanych $z$ wydawaniem pisma ambasady.

Niewątpliwym sukcesem referatu prasowego i ambasady było stworzenie polskiej gazety na terytorium Związku Radzieckiego. Pierwszy numer „Polski" ukazał się 4 grudnia $1941 \mathrm{r}$. Termin ten zbiegł się z wizytą premiera Sikorskiego na Kremlu i podpisaniem deklaracji o przyjaźni i wzajemnej pomocy.

O nazwie gazety tak napisano w artykule Do naszych czytelników, opublikowanym w numerze 5 (7): „Nazwaliśmy je tytułem najprostszym i najwspanialszym, jaki znamy. Nazwaliśmy je tym słowem, któreście Wy, Polacy w Rosji, powtarzali przez te dwa lata jak słowa najświętszej modlitwy, największej tęsknoty, najgorętszej miłości. Pismo nasze nazywa się Polska, bo Polska jest celem naszych walk i cierpień; bo Polska jest tym, co jest dla nas najdroższym; co nas łączy" ${ }^{15}$.

Pismo wydawane było $\mathrm{w}$ formacie $29 \times 41 \mathrm{~cm}^{16}$. Wkrótce okazało się, iż nie będzie można utrzymać zakładanej tygodniowej regularności. Przyczyniły się do tego nie tylko względy natury technicznej, co byłoby zrozumiałe, ale również cenzuralnej.

13 IPMS, PRM, sygn. PRM 41/2.

14 AWPRF, sygn. f. 122, op. 24, p. 186, d. 1, s. 96-99.

15 „Polska”, nr 5 (7) z 25 lutego 1942.

16 Szersze informacje na temat tego wydawnictwa patrz: A. Korzon, „Polska” - pismo ambasady RP w ZSRR w latach 1941-1943, „Z dziejów stosunków polsko-radzieckich. Studia i Materiały", t. IX-XII, Warszawa 1975. 
Dopiero po interwencji u Stalina zezwolono drukować „Polskę” w drukarni, która miała czcionki łacińskie (wydawała m.in. „Moscow News”). Drukarnia ta była bardzo przeładowana, długo przetrzymywała rękopisy bez składania, brak polskich zecerów powodował, że korekta była bardzo niestaranna ${ }^{17}$. Podjęto $\mathrm{w}$ związku $z$ tym starania o sprowadzenie matryc z polskimi czcionkami.

Istnienie cenzury $\mathrm{w}$ komunistycznych strukturach jest niemalże standardem. Nie dziwi więc, że redakcja pisma była przez nią silnie skrępowana. W ZSRR w czasie wojny nosiła ona dwoisty charakter: formalnie przeprowadzał ja Wydział Prasowy LKSZ, a faktycznie decyzje podejmowała Cenzura Wojenna, która oficjalnie nie występowała i ambasada nie miała $z$ nią nigdy bezpośrednich kontaktów ${ }^{18}$. Ta swoista niesamodzielność organu cenzuralnego, oczekiwanie w „drażliwych punktach" na wskazówki, przyczyniało się $\mathrm{w}$ poważnym stopniu do wydłużania terminu wydawania numerów gazety.

Doświadczenia polskie z cenzurą radziecką dowodziły, że absolutnie niedopuszczalne było publikowanie jakichkolwiek materiałów dotyczących terytoriów polskich sprzed 1939 r., pierwszych miesięcy wojny, losów polskich uchodźców z ZSRR, czy polemika $z$ artykułami publikowanymi na łamach polskojęzycznych pism firmowanych przez komunistów, czyli „Nowych Widnokręgów” i "Wolnej Polski”. Artykuły (także audycje radiowe) o takiej tematyce były natychmiast cofane przez radziecką cenzurę. $\mathrm{Z}$ tego powodu dochodziło do konfliktów, choć oczywistym jest, że redakcja „Polski” była z góry na przegranej pozycji, a jedynym możliwym kompromisem była rezygnacja $z$ umieszczania konfliktowego materiału.

Ciekawą ilustrację cenzury, jaka dotknęła utwory Władysława Broniewskiego, zamieszcza w swojej pracy Feliksa Lichodziejewska. Dla przykładu, w wierszu Droga, który ukazał się w numerze „Polski” z 18 grudnia, w oryginale jeden z wersów brzmiał: „Ja te norweskie wystrzały w celi słyszałem nad Moskwą", zmieniono „w celi” na „tutaj” ${ }^{19}$. Innego utworu zatytułowanego Zamieć w ogóle nie pozwolono opublikować. Przez radziecką cenzurę nie przeszły następujące słowa:

17 A AN, Ambasada w Związku Radzieckim, sygn. r. 32A, b. 24, f. 5, z. 873.

18 Notatka o praktykach cenzury prasowej w stosunku do wydawnictw polskich. Archiwum Wschodnie Ośrodka Karta (dalej AW), Kopie akt z Instytutu Hoovera (dalej HI), Zespół akt Ministerstwo Informacji i Dokumentacji, sygn. V/MID/93/116.

19 F. Lichodziejewska, Broniewski bez cenzury 1939-1945, Warszawa 1992, s. 31. 


\section{„O, jakże smutno przez ten krwawy świat \\ iść cmentarzyskiem idej. \\ Wiatr w oczy wieje, orenburski wiatr. \\ Szedłem. Iść będę. Idę!" ${ }^{20}$.}

Kłopoty $z$ drukowaniem i cenzurą, pogłębione dodatkowo przez permanentny brak papieru, uniemożliwiły regularne wydawanie gazety. W sumie w grudniu 1941 r. ukazał się jeszcze jeden czterostronicowy numer ${ }^{21}$, natomiast w ciągu całego 1942 r. wyszło ich zaledwie 18. Pracownikom redakcji udało się zwiększyć objętość pisma do 12 stron (a nawet $16 \mathrm{w}$ czerwcu, wrześniu i październiku). Od stycznia 1943 r. „Polska” zaczęła ukazywać się już regularnie, ale w odstępach dwutygodniowych w objętości 8 stron. Do momentu zerwania stosunków dyplomatycznych wydanych zostało ogółem 27 numerów w nakładzie 10 tysięcy egzemplarzy każdy.

Nie była to ilość odpowiadająca wymaganiom, dlatego też redaktorzy gazety zwrócili się do swoich czytelników z następującym apelem: "Obowiązkiem każdego oświeconego Polaka jest, aby numer, jaki wpadł w jego ręce, nie utkwił, nie zginął, aby obiegł jak sztafeta jak najszersze koło rodaków [...] z pisma należy przede wszystkim robić "gazety ścienne« we wszystkich naszych punktach dworcowych, lokalach delegatur, przedszkolach" 22. Ataszat podjął również próbę, niestety nieudaną, zwiększenia nakładu do 20 tysięcy ${ }^{23}$.

Zespół redakcyjny „Polski” był stosunkowo skromny. Do lipca 1942 r. liczył on łącznie $z$ administracją od czterech do sześciu osób. Najtrudniejszym okresem dla pisma był zapewne grudzień 1942 r., kiedy to przez większą część miesiąca pracę redakcyjną wykonywała zaledwie jedna lub dwie osoby. Od końca grudnia 1942 r. na stałe w redakcji pracowały cztery osoby. Redaktorem naczelnym "Polski” był attaché prasowy.

Jak już wspomniałam wyżej, $z$ referatem prasowym, a także $z$ redakcja „Polski” współpracowało wielu znakomitych polskich dziennikarzy i pisarzy. Redakcja starała się bowiem w miarę możliwości korzystać z pomocy nie tylko szerokiego grona pracowników ambasady - często przecież fachowców $z$ różnych dziedzin - ale również wykorzystywać teksty nadsyłane przez Po-

20 Ibidem, s. 33.

21 Miało to miejsce 18 grudnia. W numerze zamieszczono przemówienie generała Sikorskiego, nadane w radiu 4 grudnia 1941 r., zdano również krótką relację z tej wizyty. „Polska”, nr 2 z 18 grudnia 1941.

22 Do naszych czytelników, „Polska”, n 5 (7) z 25 lutego 1942.

23 AWPRF, sygn. f. 0122, op. 25g, p. 188, d. 2, s. 66-71. 
laków przebywających na terytorium ZSRR. „Polska” publikowała także przedruki z innych polskich pism emigracyjnych. Zdarzało się również, że redakcja zamawiała specjalne artykuły u publicystów mieszkających poza Związkiem Radzieckim. Wiele miejsca na łamach gazety zajmowały teksty przemówień ambasadorów, prezydenta i premiera RP, skierowane do szerokiej masy polskich obywateli zamieszkujących na terytorium ZSRR. Poczytne miejsce zajmował dział zatytułowany „Skarbnica Literatury Polskiej", w którym zamieszczano w całości krótsze utwory, a częściej fragmenty dzieł Mickiewicza, Słowackiego, Żeromskiego, Sienkiewicza, Orzeszkowej i wielu, wielu innych polskich literatów. Bardzo ważnym przedsięwzięciem pracowników redakcji był druk na łamach gazety elementarza dla dzieci, a po jego ukończeniu także czytanek na poziomie podręczników języka polskiego dla pierwszych klas szkoły powszechnej ${ }^{24}$.

Pamiętano również o potrzebach religijnych obywateli polskich i drukowano kazania oraz modlitwy. W numerze noworocznym (1942) zamieszczono wizerunek Matki Boskiej według rzeźby w drzewie wykonanej przez polskich jeńców wojennych ${ }^{25}$.

Łamy „Polski” służyły również innym celom. Jednym z najważniejszych była współpraca z opieką społeczną. Redagowano specjalną rubrykę „Wiadomości Opieki Społecznej", w której zamieszczano ważne dla polskich obywateli aktualności związane $\mathrm{z}$ tą dziedziną pracy ambasady. Niezmiernie ważna była również pomoc w poszukiwaniach osób zaginionych. Niemalże od początku powstania gazety istniał odrębny dział, w którym publikowane były nazwiska poszukiwanych. Doceniając ogromną wartość tego typu działań, redakcjá poświęcała tym wykazom dwie, a nawet cztery strony. Działalność tę Wydział Prasowy LKSZ przerwał w lipcu 1942 r.

15 lipca 1942 r. na spotkaniu z zastępcą Kierownika Wydziału Prasowego LKSZ Oriechowem, T. Parnicki został poinformowany, że nie zostaną awizowane listy poszukiwanych do druku, po cenzurnym soobrażenijam, nie tylko do numeru 14, ale w ogóle. Parnicki zapowiedział interwencje, ale ich efekty były oczywiste ${ }^{26}$.

24 Ciekawostką może być fakt, iż wobec braku polskiej czcionki (posługiwano się łacińską), elementarz oraz czytankę wykonywano drogą fotografowania stron, jedynego znajdującego się w posiadaniu ambasady egzemplarza podręcznika i elementarza. IPMS, AK, sygn. A.7.307/38/1.

25 „Słowo Polskie w ZSRR”, „Wiadomości Polskie” 1942, nr 11.

26 Archiwum Akt Nowych (dalej AAN), Materiały z Instytutu Hoovera (dalej HI), Zespół Ambasada w Związku Radzieckim (dalej AZR), sygn. rolka 27, box 20, folder 1, klatka 169. 
Kolportaż gazety (stosunkowo dużego nakładu jak na wojenne warunki) wzięła na swoje barki ambasada. Odbywał się on głównie na drodze wysyłkowej, poprzez mężów zaufania ambasady. Otrzymywali oni paczki z gazetami - według rozdzielnika 1 egzemplarz na pięćdziesiąt osób - które rozdysponowywali wśród ludności polskiej na podległym im terenie. Oprócz tego około stu obywateli polskich otrzymywało do rozpowszechniania paczki z gazetami - niezależnie od mężów zaufania. Rozpowszechnianie było ogromnie trudne i powolne, a oprócz tego zawsze istniała możliwość zaginięcia przesyłek. $\mathrm{Z}$ tego powodu wielu polskich obywateli zapewne nigdy nie miało w rękach "Polski”.

A trzeba podkreślić, że była ona niestety jedynym w języku polskim oficjalnym źródłem informacji dla Polaków przebywających na terytorium ZSRR. Z planowanych inicjatyw wydawniczych udało się ambasadzie zrealizować naprawdę niewiele. We wspomnianym wyżej dokumencie zakładano m.in. publikację dwutomowej tzw. Czarnej Księgi i co najmniej kilku broszur. Ostatecznie udało się jedynie opublikować w formie osobnej broszury odezwę powitalną ambasadora Tadeusza Romera do Polaków w ZSRR.

O problemach, z którymi borykał się referat prasowy, Ksawery Pruszyński w swoim raporcie napisał tak: „Uzyskawszy zasadniczą zgodę Łozowskiego złożyliśmy wszelkie żądane projekty szczegółowe aż do obliczeń czysto technicznych. Zwlekanie $z$ odpowiedzią mimo bardzo natarczywych przypominań, zasłanianie się trudnościami technicznymi, przekazywanie tych spraw coraz to innym ludziom do załatwienia, kazało wnioskować, że Sowiety tych spraw załatwić praktycznie nie chcą" ${ }^{27}$.

Warto może przypomnieć, jakie wspomnienia zachowali o "Polsce” obywatele RP przebywający wtedy na terytorium ZSRR. Maria Januszkiewicz tak opisała kontakty współmieszkańców z tym wydawnictwem: „czytali gazetę Polska - pierwsze, wolne słowo polskie od dwóch lat! Chłonęliśmy każdą linijkę, każde słowo Xawerego Pruszyńskiego, Zygmunta Nowakowskiego i innych polskich publicystów i pisarzy, przemawiających do nas z łamów tej gazety. Wiersz Antoniego Słonimskiego WSZYSTKO powtarzaliśmy ze łzami wzruszenia. Numery pisma, wyczytane przez wszystkich, wracały [...] w postaci pojedynczych listków papieru" ${ }^{28}$. Gazeta, jak wynika z tych słów,

27 Archiwum Zakładu Historii Ruchu Ludowego (dalej AZHRL), Archiwum prof. Stanisława Kota (dalej SK), sygn. SK/287.

28 M. Januszkiewicz [Jonkajts-Luba G.], Kazachstan, Paryż 1981, s. 85. 
była bardzo ważna dla nich, co potwierdzają liczne wspomnienia ${ }^{29}$. Pomagała żyć i stanowiła łączność z przeszłością, ale i dawała nadzieję na przyszłośćc ${ }^{30}$.

Drugim obok gazety środkiem informacyjno-propagandowym miały być audycje radiowe. $W$ tej dziedzinie napotkano jednak na jeszcze poważniejsze problemy niż przy pracy wydawniczej. Tak pisał o tym Pruszyński we wspomnianym wyżej raporcie: „Sprawa radia była tu szczególnie jawna. Jeśli w wypadku redakcji czy wydawnictw mogły być istotnie pewne trudności techniczne, aczkolwiek nie tak olbrzymie, to w sprawie radia nie było ich wcale. Radiostacja moskiewska udzielała polskiej redakcji 56 minut dziennie na jej audycje. Polska (kominternowska) redakcja nie miała dość materiału, aby te audycje zapełnić. 15 minut dziennie żądanych przez nas dawało się ogromnie łatwo wykroić z kominterowskiego polskiego programu" 31. Możliwości jak widać były, choć zabrakło dobrych chęci.

W efekcie rząd sowiecki oddał do dyspozycji ambasady cztery 10-minutowe audycje tygodniowo - dwie dla ludności polskiej w Związku Radzieckim, dwie na krótkie fale za granicę, do Polski. Programy dla terytorium ZSRR nadawane były we wtorki i soboty o godz. 17.20 czasu moskiewskiego na fali $460 \mathrm{i}$ według informacji ambasady nie były na pewno słyszane w grudniu $1941 \mathrm{r}^{32}$ Nie udało się zdobyć informacji o ich zasięgu, poza bliskim promieniem wokół Kujbyszewa. Na pewno były słuchane $\mathrm{w}$ wojsku ${ }^{33}$.

Programy nadawano, ale Polacy w większości nie mogli ich słuchać. Jak się bowiem okazało największym problemem nie był opór władz radzieckich, ale zupełnie coś innego, a mianowicie brak odbiorników radiowych w miejscach przebywania polskich obywateli. Gros aparatów został praktycznie odebrany przez władze radzieckie (w czasie wojny nie można było ich posiadać), a jedyną możliwość słuchania radia stwarzały głośniki,

29 Patrz: Wschodnie losy Polakǿw, red. i opr. W. Myśliwski, t. 1-5, Lomża 1991-1996; Wspomnienia Sybiraków, t. 1-9, Warszawa 1990-1997.

30 Należy nadmienić, iz wydawnictwo to doczekało się również krytyki. A. Kórzon napisał, być może nie bez racji, że "Polska” mogłaby „oddać znacznie większe usługi Polakom w Związku Radzieckim, gdyby celom politycznym rządu nie podporządkował interesów setek tysięcy Polaków w Związku Radzieckim". A. Korzon, op. cit., s. 272.

31 Ibidem.

32 AAN, HI/AZR, sygn. r. 28, b. 20, f. 6, k. 344 .

33 AAN, HI/AZR, sygn. r. 32A, b. 24, f. 5, k. 872. 
które nastawione były na program oficjalny. Lokalne stacje nie transmitowały audycji polskich nadawanych z Kujbyszewa, tak więc Polacy po prostu nie mogli ich słyszeć, choć jak pisze Pruszyński „ważne informacje przedosta ją się wszędzie, nawet bez instytucjonalnych środków rozpowszechniania" 34 .

Ambasada wielokrotnie monitowała Wydział Prasowy LKSZ w tej sprawie, ale strona radziecka udzielała przez blisko rok wymijających odpowiedzi, by w końcu oświadczyć, że nie istnieje możliwość przełączenia audycji ambasady na sieć lokalnych - republikańskich i obwodowych - stacji. W praktyce zatem niemożliwością stało się nawiązanie kontaktu drogą radiowa ambasady $z$ obywatelami polskimi $z$ terytorium ZSRR.

Trzeba powiedzieć, niestety, ponieważ była to doskonała sposobność do informowania polskich obywateli o najważniejszych dla nich sprawach ${ }^{35}$. $\mathrm{Na}$ audycje radiowe składały się bowiem wiadomości opieki społecznej i przemówienia. Na samym początku wypowiadał się głównie Pruszyńskiª , ale kilka następnych audycji wypełniły przemówienia premiera Sikorskiego i ambasadora Kota. Planowano również umieścić w programie wystąpienia Andersa, ks. Kucharskiego ${ }^{37}$.

Tym bardziej należy żałować, że nie udało się utrzymać na antenie radia radzieckiego polskich programów, kiedy przeczyta się wspomnienia jednego z polskich zesłańców: „Pewnego dnia w naszym smutnym życiu pojawił się promień radości i nadziei na lepsze jutro. Radio sowieckie podało, że między Stalinem a generałem Sikorskim, premierem rządu emigracyjnego i Naczelnym Wodzem, zostało zawarte porozumienie [...] Przeżywaliśmy uniesienie i szał radości. Słuchaliśmy przez radio, udostępnione nam przez władze, przemówienia generała Sikorskiego do Polaków znajdujących się na Syberii [...] A potem usłyszeliśmy Jeszcze Polska nie zginęła"38. I choćby ten polski hymn, grany na zakończenie każdej audycji, był im wszystkim tak samo chyba potrzebny jak chleb.

Bardzo ważne były również podawane na zakończenie audycji wiadomości opieki społecznej. W jednej z pierwszych przestrzegano polskich obywa-

\footnotetext{
34 K. Pruszyński, op. cit, s. 143.

35 „Polska”, jak wiemy, miała kłopoty z kolportażem, a poza tym chyba nie wszyscy Polacy potrafili czytać.

36 „Komunikat radiowy z 12 października 1941 r., odczytany przez K. Pruszyńskiego”, AZHRL, SK, sygn. SK/287.

37 AAN, HI/AZR, sygn. r. 32A, b. 24, f. 5, k. 872 .

38 H. Łupanowiczowa, Skrzywdzeni, w: Z nieludzkiej ziemi do Polski, opr. K. Dominiak, Bydgoszcz 1991, s. 177.
} 
teli przed opuszczaniem miejsc pobytu, informowano o pomocy, „którą mogą otrzymać dzięki hojności krajów sprzymierzonych", o powołaniu delegatów i mężów zaufania. Wspomniano o decyzji rządu radzieckiego w sprawie przedłużenia ważności paszportów. Zapowiedziano, że w następnych wiadomościach będą informacje o sposobach poszukiwania najbliższych i przekazywania informacji poza granice ZSRR ${ }^{39}$. W wiadomościach opieki społecznej nr 3 po raz kolejny poruszono sprawę paszportów. Podano, że w związku z niemożliwością zorganizowania trybu wydawania ich przez ambasadę, zajmą się procedurą ich wystawiania delegaci i do nich będzie można się zwracać w tych sprawach. Poinformowano również o podjętych przez ambasadę staraniach wokół tworzenia sierocińców ${ }^{40}$. Dobrze by było, gdyby te wszystkie komunikaty docierały do zainteresowanych. Pomogłyby im radzić sobie w trudnej, radzieckiej rzeczywistości.

O problemach, które tak licznie pojawiały się przy realizacji akcji propagandowej dla Polaków w ZSRR, rozmawiali z Łozowskim 24 czerwca $1942 \mathrm{r}$. Pruszyński i Tabaczyński ${ }^{41}$. Ze strony przedstawicieli ambasady padło wiele zarzutów. Według strony polskiej współpraca nie układała się dobrze, redakcja „Polski” miała trudności $z$ wydawaniem gazety nawet raz na 6 tygodni. Główną przyczynę tego stanu rzeczy upatrywano w cenzurze, która przetrzymywała materiały nawet dwa miesiące. Podkreślano również, że wciąż nie dostarczono, pomimo wielu obietnic, polskich czcionek ${ }^{42}$. Niemożliwe było wciąż wydanie zaplanowanych we wrześniu 1941 r. książek i broszur. Łozowski był zdziwiony tymi oskarżeniami, ale obiecywał życzliwą pomoc w przezwyciężaniu problemów. Kłopoty jednak pozostały.

Jak wynika $z$ pisma ambasady do LKSZ z 13 marca 1943 r., matryc z polskimi czcionkami, przynajmniej do dnia wystosowania listu, nie otrzymano pomimo wielokrotnych zapewnień Zastępcy Naczelnika Wydziału Prasowego LKSZ (15 grudnia 1942 r., 18 lutego i 11 marca 1943 r.) ${ }^{43}$.

Audycje polskie wciąż nie docierały do polskich obywateli. O tym fakcie rozmawiał jeszcze 16 listopada 1942 r. ambasador Tadeusz Romer z Łozow-

39 AAN, HI/AZR, sygn. r. 29, b. 20, f. 1, k. 80-82.

40 Ibidem, k. 83-84.

41 AWPRF, sygn. f. 0122 , op. 25g, p. 188, d. 2, s. 66-71.

42 Dość „ciekawa” uwagę na ten temat zamieściła w swoim dzienniku Janina Broniewska: „Bardzo biadolą, ze mają tylko łacińskie czcionki, ze zdarzaja się przeto chochliki mimowolne w rubryce kazań. Czasem nawet pikantne, to fakt. Zwłaszcza w Słowie Bożym". J. Broniewska, Z notatnika korespondenta wojennego, t. 1, Warszawa 1954, s. 24.

43 AAN, HI/AZR, sygn. r. 1, b. 1, f. 3, k. 608. 
skim ${ }^{44}$. Proponował nawet, aby użyć do przekazu tzw. radio-uztów. W odpowiedzi usłyszał od Łozowskiego, że byłoby to niemożliwe technicznie, ponieważ „te tzw. radio-uzty są używane tylko tam gdzie są skupiska, to znaczy w fabrykach, klubach, kołchozach itp. Polacy są natomiast rozproszeni po całym naszym terytorium".

Wobec braku innej możliwości, oddane do dyspozycji ambasady cztery „wejścia radiowe" zostały ostatecznie wykorzystane przez ambasadę. Wszystkie bowiem zaczęto traktować jako przeznaczone dla Polaków w Kraju, tworząc w ten sposób blok audycji na Kraj. W efekcie nadano około sześciuset dziesięciominutowych audycji, a przy okazji ważniejszych świąt piętnastominutowych ${ }^{45}$.

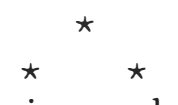

Głównym narzędziem działania w zakresie pracy informacyjno-propagandowej w stosunku do czynników sowieckich miały być nie tylko oficjalne i mniej oficjalne kontakty z przedstawicielami radzieckiej literatury i nauki, ale również wydawany przez ambasadę biuletyn w języku rosyjskim oraz publikowanie polskich materiałów w prasie radzieckiej. Niestety, osiągnięcia referatu prasowego na tej płaszczyźnie okazały się minimalne. Nawiązanie bliższych kontaktów $z$ radzieckimi uczonymi czy pisarzami, a tym bardziej wpłynięcie na ich stanowisko w kwestii stosunków polsko-radzieckich okazało się zadaniem bardzo trudnym. Śniadanie wydane przez ambasadora Stanisława Kota dla Aleksego Tołstoja oraz rozmowy Ksawerego Pruszyńskiego i Teodora Parnickiego z Ilją Erenburgiem stały się najefektowniejszymi „osiągnięciami” w zakresie kontaktów osobistych. Kolejne rozmowy Parnickiego $z$ mało znanymi przedstawicielami radzieckiej literatury i nauki pozwalały zorientować się, jakie było stanowisko średniej inteligencji w stosunku do Polski i Polaków. Uzyskanie nawet skąpych informacji wymagało naprawdę wielu zabiegów, ponieważ wszyscy rozmówcy rozpoczynali spotkanie od „deklaracji absolutnej wiary w mądrość Stalina, doskonałość sowieckiego systemu, i paroma innymi dogmatami charakteryzu jącymi główną linię partii" ${ }^{46}$.

Podobnie rzecz się miała $z$ projektami dotyczącymi biuletynu ambasady i zamieszczania jej materiałów w prasie radzieckiej. Poza zdawkowymi, nie-

44 AAN, Zespół akt Poselstwo RP w Teheranie (dalej PT), sygn. 91, s. 41-47.

45 IPMS, AK, sygn. A.7.307/38/1.

46 K. Pruszyński, Noc na Kremlu, Warszawa 1989, s. 152. 
zobowiązującymi rozmowami w tej sprawie nie znalazły one żadnego przełożenia w wydawnictwach. Co prawda, w styczniu 1942 roku „Istoriczeskij żurnał" zamówił u Pruszyńskiego studium o udziale Polaków w walkach o Norwegię, które zostało nawet przełożone na język rosyjski i dostarczone do redakcji. Nigdy się jednak nie ukazało na łamach tego czasopisma ${ }^{4}$.

Od października 1942 roku ambasada zaczęła również systematycznie przekazywać kierownictwu Sowinfombiura i Ludowemu Komisariatowi Spraw Zagranicznych rosyjskie przekłady ważnych politycznie informacji pozyskiwanych przez referat prasowy z Polskiej Agencji Telegraficznej. Nie wiadomo, w jaki sposób zostały one wykorzystane przez stronę radziecką.

Wobec nieudanych starań referatu w zakresie propagandy prasowej na łamach gazet radzieckich, w grudniu 1942 r. ambasador Romer rozważał możliwość nadawania przez ambasadę audycji radiowych w języku rosyjskim $^{48}$. Na skutek zaostrzających się od początku 1943 r. stosunków polsko-radzieckich projekt ten na zawsze już pozostał w sferze życzeń.

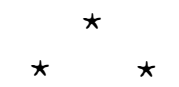

Na płaszczyźnie oddziaływania propagandowego na cudzoziemców (zarówno na koła dyplomatyczne, jak i dziennikarskie) podstawowym narzędziem były spotkania na gruncie towarzyskim. Wydaje się, że najszersze kontakty nawiązał i utrzymywał Ksawery Pruszyński, głównie z przedstawicielami narodów słowiańskich ${ }^{4}$. Po opuszczeniu przez niego Związku Radzieckiego obowiązki w tym względzie przejęła attaché ambasady Natalia Aszkenazy, która z kolei pielęgnowała kontakty z dyplomatycznymi kołami anglosaskimi.

Podkreślić należy, że również i na tej płaszczyźnie pracownicy referatu napotykali na trudności. Najbardziej sprawy propagandy komplikował fakt, iż od wiosny 1942 r. dziennikarze zagraniczni przebywali w Moskwie, podczas gdy placówki dyplomatyczne nadal w Kujbyszewie ${ }^{50}$. Wpływ działalności referatu prasowego w tym okresie musiał być niestety znikomy. Sytuacja uległa nieznacznej poprawie w czasie pobytu ambasadora Tadeusza

47 IPMS, AK, sygn. A.7.307/38/1. Podobno redaktor naczelny tego czasopisma zamawiał teksty również u innych publicystów, m.in. u Parnickiego. AAN,HI/ AZR, sygn. r. $32 \mathrm{~A}$, b. 24, f. 5, k. 873.

48 AAN, PT, sygn. 91, s. 41-47.

49 Niewiele, niestety, możemy powiedzieć o efektach tych kontaktów.

50 Jak wiadomo jesienią 1941 r. korpus dyplomatyczny i większość r adzieckiego rządu przeniesiono do Kujbyszewa w związku z zagrożeniem Moskwy niemiecką of ensywą. 
Romera w Moskwie. Okres ten przyniósł intensyfikację kontaktów z dziennikarzami zagranicznymi dzięki bezpośredniej działalności ambasadora (konferencji prasowych i wywiadów). W Kujbyszewie w tym czasie kontakty z cudzoziemcami (głównie $\mathrm{z}$ redakcją organu prasowego ambasady brytyjskiej „Britanskij Sojuznik”, wydawanego w języku rosyjskim) organizował nowy attaché prasowy Jan Erdman.

Jedną z konferencji prasowych w Narkomindiele oraz świat zagranicznych korespondentów interesująco opisuje Pruszyński ${ }^{51}$. Wśród „asów międzynarodowego dziennikarstwa" pracującego w ZSRR wymienia Philipa Jordana z "News Chronicle", Collertona z "Daily Telegraph”, Lovella z „Reutera", Alexandra Wertha z "Timesa", Sillzbergera z "New York Timesa". Podkreślił jednocześnie trudności, jakie stwarzano dziennikarzom w Związku Radzieckim: „Sowieckie władze, zawsze niezwykle podejrzliwe w stosunku do zagranicznych dziennikarzy, podwoiły bowiem środki ostrożności. Nie pokazywano im niczego. Nie mówiono nic. Racjonowano informacje do niewyobrażalnie absurdalnych granic" 52 .

Bardzo istotnym narzędziem rozpowszechniania polskiego stanowiska był wydawany od początku 1943 roku biuletyn ambasady w języku angielskim przeznaczony dla innych placówek dyplomatycznych. Umożliwiał on zapoznanie szerokiego grona korpusu dyplomatycznego w Kujbyszewie z niedostrzeganym przez pryzmat prasy radzieckiej stanowiskiem polskiego rządu w różnych kwestiach politycznych. Biuletyn ten redagowany był przez Natalię Aszkenazy i Jana Erdmana ${ }^{53}$. Szkoda, że wydawany był zaledwie przez kilka ostatnich miesięcy działania ambasady, choć nie sądzę, by mógł on radykalnie wpłynąć na zmianę stosunku przedstawicieli korpusu dyplomatycznego do spraw polskich.

Stanowisko ambasady przybliżała również dyplomatom „Polska”, którą wysyłano w trzech egzemplarzach do ambasad: australijskiej, amerykańskiej, tureckiej, angielskiej, czechosłowackiej, irańskiej, chińskiej, norweskiej, jugosłowiańskiej, afgańskiej oraz poselstw: greckiego, belgijskiego, saudy jskiego, francuskiego, kanadyjskiego ${ }^{54}$.

Niestety, niezbyt dobrze świadczy o pracy referatu w tym zakresie treść rozmowy korespondenta „United Press" - Chandlera z Łozowskim, odbytej

51 K. Pruszyński, Noc na.., s. 37-39.

52 Ibidem.

53 Niestety nie udało mi się dotrzeć do żadnego numeru tego biuletynu.

54 AAN, HI/AZR, sygn. r. 28, b. 20, f. 5, k. 194. 
21 lipca 1942 r. ${ }^{55}$ Oświadczył on, że „polska a mbasada prowadziła i prowadzi systematycznie antysowiecką propagandę pośród korpusu dyplomatycznego w Kujbyszewie, polegającą na rozpowszechnianiu zmyślonych oszczerstw na temat stosunku władz radzieckich do Polaków w ZSRR". Pytał Łozowskiego, czy może o tym napisać artykuł, a na zakończenie ostrzegał, że przygotowuje się pols ka kampania antyradziecka. Miejmy nadzieję, iż takiego nieprzyjaznego stanowiska nie prezentowali inni dziennikarze zagraniczni.

Trudno z perspektywy lat ocenić tak ulotną działalność, jaką jest praca dziennikarska. Zachowały się, co prawda, egzemplarze gazet, a nawet zapisy niektórych audycji radiowych. Ale czy można jednoznacznie powiedzieć, jak te informacje wpływały na życie Polaków w ZSRR? Czy prowadzona propaganda docierała do ludzkich serc i umysłów?

Wiemy jednak, choć tylko ze strzępów wspomnień Polaków z ZSRR, że „Polska" i nawet te nieliczne polskie audycje stanowiły ważny element ich zesłańczego życia. Dawały im nadzieję. I rzeczywiście były traktowane, tak jak pragnął Pruszyński, jak „uścisk dłoni brata, który pomóc jeszcze nie może. Ale brata, który pamięta" ${ }^{56}$.

55 AWPRF, sygn. f. 122 , op. 25, p. 188, d. 2, s. 88-91.

56 Do naszych czytelników, „Polska”, nr 5(7) z 25 lutego 1942. 